\title{
POST-FIRE FAUNA OF CARABID BEETLES (COLEOPTERA, CARABIDAE) IN FORESTS OF THE MORDOVIA STATE NATURE RESERVE (RUSSIA)
}

\author{
Alexander B. Ruchin 1,*, Sergei K. Alekseev², Anatoliy A. Khapugin ${ }^{1,3}$ \\ ${ }^{1}$ Joint Directorate of the Mordovia State Nature Reserve and National Park «Smolny», Russia \\ *e-mail: ruchin.alexander@gmail.com \\ ${ }^{2}$ Ecological club «Stenus», Russia \\ ${ }^{3}$ Tyumen State University, Russia
}

Received: 18.11.2018. Revised: 23.01.2019. Accepted: 27.01.2019.

\begin{abstract}
Wildfires are among the basic ecological factors that change habitats and initiate the succession of new forest communities. Burned areas are ephemeral habitats presenting a broad range of ecological niches that many insect species may exploit. In 2016, we studied the carabid fauna in burned pine forests of the Mordovia State Nature Reserve (European Russia). Sixty carabid beetles in total were collected in an unburned (control) area and on sites damaged by crown fire and surface fire. Carabids were more numerous and diverse in the burned areas, compared to the unburned forest, while the catch index was significantly higher in unburned area. This was due to the extremely high dynamic density of Carabus arcensis on the control site, while it was ten times lower in the burned area. The number of carabid species tended to increase in the sequence unburned forest - forest impacted by surface fire - forest impacted by crown fire. Expectedly, species compositions were more similar between firedamaged areas, while there was a higher difference between the unburned site and area damaged by crown fire. Concerning trophic group classification, all carabid beetles were distinguished in two groups, zoophagous species and myxophytophagous species. In both groups, the species number increases in the sequence from unburned areas to the forest impacted by crown fire. Finally, the dynamic density of some carabids (e.g. Poecilus lepidus, P. versicolor, Harpalus tardus, H. rufipes, H. rubripes, Cicindela sylvatica) largely increased after fire impact, while it decreased for the most other species. Our results suggest that burning of the forest stand may support some carabid species, i.e. larger forest fire increases species richness of beetle fauna. The highest dynamic density of the carabids is maintained by a few beetle species (Carabus arcensis, C. hortensis, Pterostichus oblongopunctatus).
\end{abstract}

Key words: dynamic density, insects, species composition, trophic group, wildfire, wildfire severity

\section{Introduction}

Wildfires are the main and historically natural factor of dynamics and formation of forest biogeocoenoses. It has become catastrophic in recent years. Anthropogenic intervention leads to an increase in number and size of fires, changes in their frequency, seasonality, strength (Brown, 2006; Carcaillet et al., 2007; Sieber et al., 2013; Zaitsev et al., 2016; Erni et al., 2017; Aakala et al., 2018; Hornberg et al., 2018). Post-fire soil changes depend on the intensity of fire largely (Certini, 2005; Buddlea et al., 2006; Garcia-Orenes et al., 2017; Sazawa et al., 2018). An important aspect for soil animals is the disappearance of litter and upper organic soil horizon (Gongalsky, 2011, 2014). In surface fire, only the lower forest tier, especially the forest floor, burns out. Under these conditions, invertebrates could extinct as a result of fire impact, as well as losing the necessary resources (Niklasson \& Granström, 2000; Swengel, 2001; Gongalsky \& Persson, 2013; Butenko et al., 2017). Under crown fire influence, the entire ecosystem could be disturbed. And then all forest tiers perish. In such severely burned areas, the diversity and the number of the invertebrate species are significantly reduced (Gongalsky et al., 2008; Arnold et al., 2017; Koltz et al., 2018). However, after a certain time, the biodiversity is being restored in ecosystems affected by wildfire. In each case, the process of biodiversity restoring takes a certain time (Coleman \& Rieske, 2006; Moretti et al., 2006; Kral et al., 2017).

According to historical documents and observations of the Mordovia State Nature Reserve staff, significant wildfire evidences in the Protected Area have been recorded in 1842, 1899, 1932, 1972 and 2010 (Kuznetsov, 1960; Grishutkin, 2012). The frequency and intensity of fires has increased precisely in the last two centuries in accordance with paleoecological data (Sieber et al., 2013; Novenko et al., 2018; Šamonil et al., 2018; Stambaugh et al., 2018). The 2010 fires were especially significant, as their area was $38 \%$ of the total area of the Mordovia Reserve. The damage degree of the forest area was unequal in different parts of the Mordovia Reserve (Grishutkin, 2012; Ruchin, 2016; Khapugin et al., 2016). These consequences began to play a certain 
role in the insect distribution (Ruchin \& Egorov, 2018; Ruchin \& Mikhailenko, 2018; Ruchin et al., 2018). This study was aimed to study the carabid fauna in the forests of the Mordovia State Nature Reserve, affected by the 2010 fires.

\section{Material and Methods}

The present study has been conducted in the Mordovia State Nature Reserve (Central Russia). The Mordovia State Nature Reserve is situated in the southern boundary of the taiga natural zone $\left(54^{\circ}\right.$ $42^{\prime}-54^{\circ} 56^{\prime} \mathrm{N} 43^{\circ} 04^{\prime}-43^{\circ} 36^{\prime} \mathrm{E}$; up to $190 \mathrm{~m}$ a.s.1.), in Central Russia (Fig. 1). The total area of the Mordovia Reserve is $321.62 \mathrm{~km}^{2}$. Forest communities cover $89.3 \%$ of the total area of the Mordovia Reserve. Soils are classified as predominantly sand with varying podzolisation degree. These lie on the ancient alluvial sands. Sandy peaty podzolic soils are also widely spread on sands with a fairly high level of ground water. Sandy podzolised soils are located under deciduous forests. Easily loamy soils are distributed under the same conditions but much less frequently (Kuznetsov, 1960). The mean annual precipitation in this area varies from 406.6 to $681.3 \mathrm{~mm}$ depending on the year. The mean annual air temperature is $4.7^{\circ} \mathrm{C}$. Maximal temperature values are registered in July, and minimal in February (Bayanov, 2015). The vegetation cover of the Mordovia Reserve is similar to the taiga complex with some features of nemoral communities. Participation of forest-steppe elements is also typical for this area (Tereshkin \& Tereshkina, 2006).

In this study, we studied ground beetles $(\mathrm{Ca}-$ rabidae), which have a high biodiversity. They are considered as indicators of many ecosystem processes (Koivula, 2011). During May - July 2016, we collected the material using pitfall traps. They were represented by 0.5 -litre cups with $4 \%$ formalin solution. We established one transect per habitat. Each transect contained 10 pitfall traps distant at $1.0-1.2 \mathrm{~m}$ of each other. We checked the pitfall traps every $10-12$ days.

A characteristic of the 2010 wildfire is presented in Table 1. The percentage of the fire-damaged forest area was assessed visually. Fire severity was assessed according to Ryan (2002) and Turner et al. (1994) with modifications. Assessment of the fire intensity was carried out according to the Fire Intensity Risk System (BC Wildfire Service, 2018).

We thus studied five $100 \mathrm{~m} \times 100 \mathrm{~m}$ plots. Site UB (control) is an unburned plot with typical mixed (Pinus sylvestris L. - Tilia cordata Mill.) forest located at $0.5 \mathrm{~km}$ of the 2010 wildfire border. Site SF is a plot changed by light surface burn. Three sites burned by crown fire were located at $2 \mathrm{~km}$ (CF2, quarter 302), $4 \mathrm{~km}$ (CF3, quarter 278) and $5 \mathrm{~km}$ (CF1, quarter 275) of the 2010 wildfire border (Fig. 1). Species composition and structure of post-fire communities were similar to vegetation studied by Khapugin et al. (2016) under similar conditions. The sites CF1, CF2, CF3 had a similar vegetation cover. It was represented by a dead forest (Pinus sylvestris) stand, scattered undergrowth of secondary trees (Betula pendula Roth, Populus tremula L.), separated herbs (Epilobium angustifolium L., Pteridium aquilinum (L.) Kuhn, Convallaria majalis L., Calamagrostis epigejos (L.) Roth). (see also Shugaev et al., 2015; Khapugin et al., 2016). Before the wildfire impact, the SF site was a typical lichen (Cladonia spp.) pine forest. In 2016, about 65-70\% of the forest stand was dead. The ground layer was completely destructed. Young secondary trees (Betula pendula, Populus tremula L.) represented the undergrowth layer. The herb layer included predominantly Epilobium angustifolium, Pteridium aquilinum, Calamagrostis epigejos, Convallaria majalis, Rubus saxatilis L., etc. (see also Shugaev et al., 2015, Khapugin et al., 2016). As a control (unburned) site, we considered lichen-moss pine forest with Sorbus aucuparia L. and Frangula alnus Mill. undergrowth. In the herb layer, Pteridium aquilinum was a dominant species. Amongst other species, Convallaria majalis, Melampyrum pratense L., Vaccinium vitis-idaea L., Calamagrostis epigejos, Rubus saxatilis occurred with a high abundance.

To analyse the data from the sites affected by crown fire (CF1, CF2, CF3), we averaged and presented them in a single data set as CF. The dynamic density of the beetles was represented as a number of beetle specimens caught per 100 traps per one day (ex./100 trap-days). In total, we collected and processed more than 2000 adult specimens during the study period. We did not count larvae. To count the dynamic density of the species, we distinguished all species into four dominance groups: dominant species ( $>5 \%$ dynamic density), subdominant species (2-5\% dynamic density), low-abundant species (1$2 \%$ dynamic density), rare species $(<1 \%$ dynamic density). We presented ecological characteristics of the carabid species according to the life-form classification of Sharova (1981). So, in this study, we distinguished two life forms: zoophagous (or "carnivorous beetles" according to Hengeveld, 1980) (i.e. feeding on animals) and myxophytophagous (i.e. feeding on both plants and animals with clear adaptation to phytophagy) carabids. 


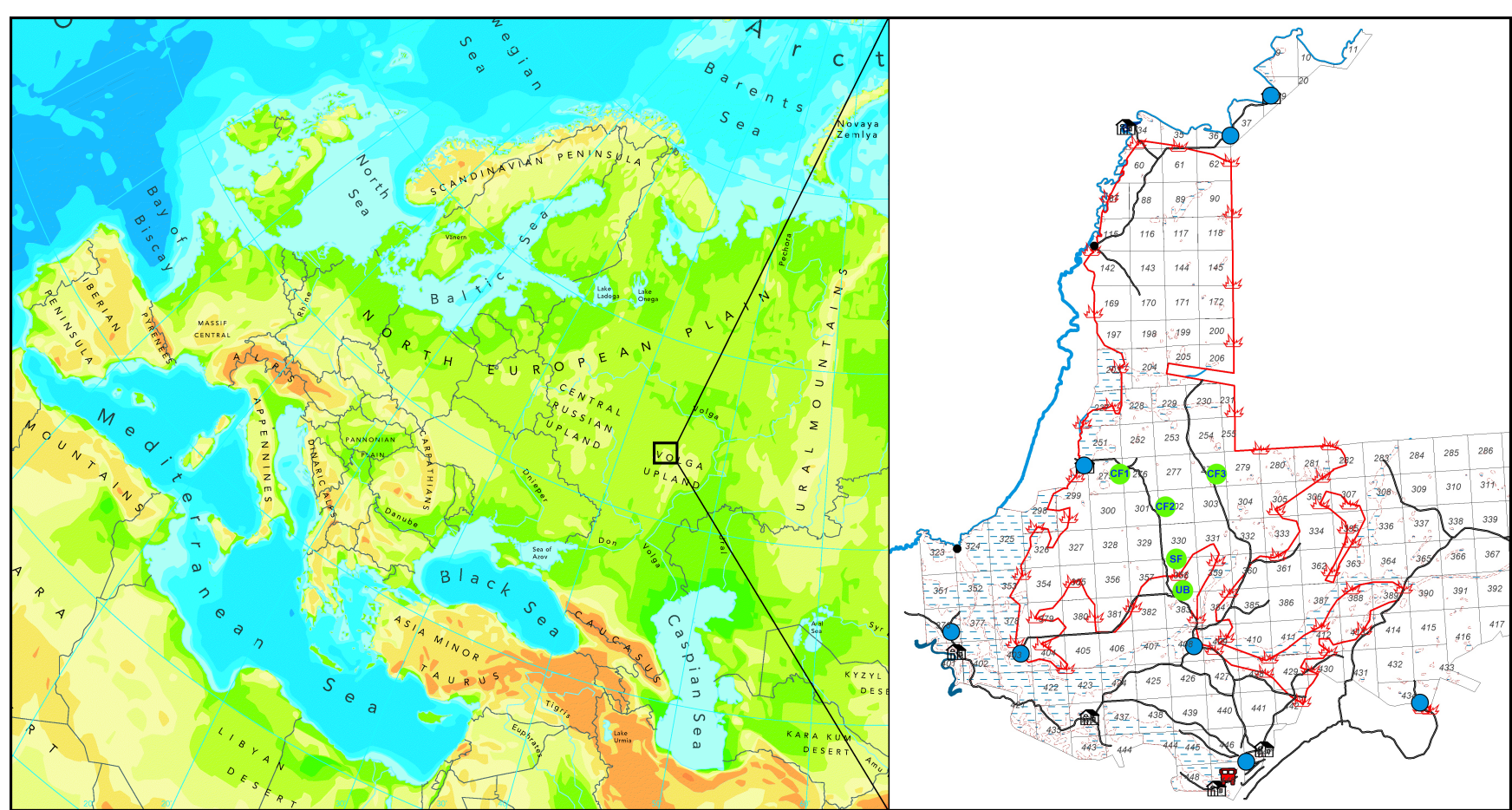

Fig. 1. Geographical position of the Mordovia State Nature Reserve in Europe. Study plots on map of the Mordovia Reserve are indicated in the list of studied locations. Red lines show wildfire borders in August 2010. Blue dots are residential or nonresidential buildings (cordons).

Table 1. Characteristic of the wildfire in 2010 per each established plot

\begin{tabular}{|c|c|l|l|}
\hline Plots & $\begin{array}{c}\text { Percent of area } \\
\text { burned, } \%\end{array}$ & \multicolumn{1}{|c|}{ Severity } & \multicolumn{1}{c|}{ Intensity } \\
\hline CF1 & 90 & 3 (Crown fire) & 6 (A blow up or conflagration; extreme and aggressive fire behaviour) \\
\hline CF2 & 90 & 3 (Crown fire) & 6 (A blow up or conflagration; extreme and aggressive fire behaviour) \\
\hline CF3 & 90 & 3 (Crown fire) & 5 (Extremely vigorous surface fire or active crown fire) \\
\hline SF & 65 & 1 (Light surface burn) & 3 (Moderately vigorous surface fire) \\
\hline UB & 0 & 0 (Unburned) & - \\
\hline
\end{tabular}

We considered the Carabidae system according to Makarov et al. (2018) based on the catalogue of Kryzhanovskij et al. (1995). For the nomenclature of Carabidae Löbl \& Löbl (2017) have been followed.

To characterise the carabid species diversity, we used Shannon Index (H') and Simpson Index (S) according to Magurran (1996). We estimated the species similarity between the sites according to Jacquard Index (J) (Jaccard, 1901). All calculations have been processed using the Microsoft Excel software.

\section{Results and Discussion}

The study of the carabid fauna revealed a total of 61 species from two subfamilies (Table 2). Miscodera arctica (Paykull, 1798) was noted for the first time in the Republic of Mordovia. Amara montivaga Sturm, 1825 was noted for the first time in the Mordovia State Nature
Reserve. Miscodera arctica is of especial interest. This species is distributed in the northern part of Europe, Siberia and Northern America. In Central Europe, it is known from Germany and Poland, with isolated locations in the Swiss Alps, Tyrolean Alps (Italy) and Moravia (Czech Republic) (Divoky, 1989; Erikstad et al., 1989; Kryzhanovskij et al., 1995; Lemdahl et al., 2014). However, in European Russia it is rarely found to southward of the Nizhny Novgorod region. Notiophilus biguttatus (Fabricius, 1779), Amara ingenua (Duftschmid, 1812), A. fulva (Müller, 1776), Ophonus azureus (Fabricius, 1775) have previously been recorded once in the Mordovia State Nature Reserve (Ruchin et al., 2016). The present information expands the area of their distribution.

We counted 20 species of carabids on the control (UB) site, 31 species on the sites damaged by surface fire (SF), 49 species on sites 
damaged by crown fire (CF). In total, 56 carabid beetle species were recorded on all sites together (Fig. 2). In general, the carabid fauna on the control site of old-growth mixed forest was poor. And it was similar to the carabid fauna obtained in the mid-1970s by Feoktistov (1978). Usually a low species number in certain areas is typical on sites of the final succession stage (Niemelä et al., 2007; Paquin, 2008). The following four species were noted only on the control site: Notiophilus palustris (Duftschmid, 1812), Harpalus laevipes Zetterstedt, 1828, $H$. luteicornis (Duftschmid, 1812), and Microlestes maurus (Sturm, 1827). All these species occur non-frequently in the pine forests of the Mordovia State Nature Reserve. They have well developed wings, capable of an active flight. We identified 12 species, which were found all studied sites. The low dynamic density of carabids is also confirmed by the low values of Shannon Index on the control site, while its values are much higher on the burned sites (Table 2). A significant contribution to the dynamic density of carabids on the UB site is caused by a high abundance of Carabus arcensis Herbst, 1784. This is evidenced by the high value of Simpson Index $(S=0.661)$, whereas the dynamic density of the carabid fauna is more aligned on the $\mathrm{CF}$ and $S F$ sites $(S=0.136$ and $S=0.125$, respectively). The similarity index of the carabid species between the UB site and SF site was 0.34; between the UB site and CF site, Jaccard Index was 0.28 ; between the CF site and SF site, Jacard Index was 0.43 . Thus, the carabid species composition was expectedly most similar between sites damaged by crown fire and surface fire. At the same time, the largest dissimilarity was indicated between the control UB site and the most damaged CF site.

The nature of the dynamic density of species was opposite to the number of the carabids. So, the maximum of dynamic density was on the UB site, while its minimum was indicated on the CF site (Fig. 2). In accordance with our study, Holliday (1992) noted a lower dynamic density of carabids in burned forest areas. In contrast to our results, the author also indicated a decrease in the number of carabid species. In others studies, conducted in Finland, Canada, Norway, and Russia, authors have obtained similar results (Potapova, 1984; Ukhova et al., 1999; Gongalsky et al., 2006; Koivula \& Spence, 2006; Martikainen et al., 2006).
Carabus arcensis was the superdominant in the dynamic density on the control site. On the SF site, its dynamic density decreased approximately by a hundred times (from 227.7 ex. / 100 trap-days to $2.3 \mathrm{ex}$. / 100 trap-days). On the CF sites, its dynamic density declined approximately until 0.6 ex. / 100 trap-days. Having such a catastrophic decline in the dynamic density on the fire-damaged sites, this species has ceased to be a dominant species. Of the other carabids, common on the UB site, only the "spring» species Carabus convexus Fabricius, 1775 has slightly increased its dynamic density (from 7.7 ex. / 100 trap-days to 13.4 ex. / 100 trapdays) on the SF site. But in conditions of the $\mathrm{CF}$ site, this species was noted only as separate individuals. The majority of beetles belonging to the genus Carabus are unable to fly (except Carabus clathratus Linnaeus, 1761). In general, these carabids were extremely sensitive and almost completely disappeared on the CF sites. Surprisingly, the semi-aquatic C. clathratus, being capable to fly, has been found in the centre of the area damaged by crown fire (at $5 \mathrm{~km}$ apart the border with unburned area).

Pterostichus oblongopunctatus (Fabricius, 1787) was also a dominant species in the unburned area of the pine forests. Its dynamic density also decreased (approximately by five times) on the SF site. It has almost disappeared on the CF site. At the same time, the close species, Pterostichus quadrifoveolatus Letznner, 1852, was known by single records on the UB site, while its dynamic density was significantly higher (approximately by 15 times) on the SF site. However, its dynamic density sharply decreased to a minimum in the area damaged by crown fire. This species is considered as a pyrophilic beetle (Gongalsky et al., 2008; Trushicina et al., 2018). Another pyrophilic species is Sericoda quadripunctata (De Geer, 1774). It was found on the fire-damaged sites already in 2011 (Ruchin, 2016; Ruchin et al., 2016). However, Sericoda quadripunctata was not collected in 2016. This evidence confirms data that this pyrophilic carabid species is usually present on young burnt sites, while it does not occur there after a certain time (Burakowski, 1989; Holliday, 1991; Wikars, 1995). The apparent predominance of the above-mentioned carabids led to an increase in Simpson Index on the UB site, whereas this index was significantly lower on both burned sites, i.e. SF and CF (Table 2). 
Table 2. The composition and dynamic density of species collected on control and burned sites of the Mordovia State Nature Reserve

\begin{tabular}{|c|c|c|c|}
\hline Species & Control & Light surface burn & Crown fire \\
\hline \multicolumn{4}{|c|}{ Cicindelinae } \\
\hline Cylindera germanica (Linnaeus, 1758) & - & 0.42 & - \\
\hline Cicindela campestris Linnaeus, 1758 & - & - & 0.31 \\
\hline Cicindela sylvatica Linnaeus, 1758 & - & - & 4.46 \\
\hline \multicolumn{4}{|c|}{ Carabinae } \\
\hline Leistus terminatus (Hellwig in Panzer, 1793) & - & - & 0.15 \\
\hline Notiophilus aquaticus (Linnaeus, 1758) & - & 0.21 & 0.15 \\
\hline Notiophilus palustris (Duftschmid, 1812) & 0.21 & - & - \\
\hline Notiophilus germinyi Fauvel, 1863 & - & - & 0.31 \\
\hline Notiophilus biguttatus (Fabricius, 1779) & - & - & 0.31 \\
\hline Carabus arcensis Herbst, 1784 & 227.66 & 2.34 & 1.85 \\
\hline Carabus cancellatus Illiger, 1798 & - & 0.21 & - \\
\hline Carabus clathratus Linnaeus, 1761 & - & - & 0.15 \\
\hline Carabus glabratus Paykull, 1790 & 4.46 & 1.49 & 0.61 \\
\hline Carabus hortensis Linnaeus, 1758 & 10.21 & 0.42 & 0.15 \\
\hline Carabus convexus Fabricius, 1775 & 7.66 & 13.40 & 0.61 \\
\hline Broscus cephalotes (Linnaeus, 1758) & - & - & 0.15 \\
\hline *Miscodera arctica (Paykull, 1798) & - & 0.21 & - \\
\hline Trechus secalis (Paykull, 1790) & - & - & 2.31 \\
\hline Bembidion lampros (Herbst, 1784) & 0.85 & 7.66 & 0.61 \\
\hline Bembidion properans (Stephens, 1828) & - & 1.06 & - \\
\hline Poecilus cupreus (Linnaeus, 1758) & - & 1.06 & 2.31 \\
\hline Poecilus versicolor (Sturm, 1824) & 4.04 & 8.94 & 26.00 \\
\hline Poecilus lepidus (Leske, 1785) & - & 2.34 & 8.92 \\
\hline Pterostichus niger (Schaller, 1783) & - & 0.42 & - \\
\hline Pterostichus anthracinus (Illiger, 1798) & - & - & 0.15 \\
\hline Pterostichus minor (Gyllenhal, 1827) & - & - & 0.15 \\
\hline Pterostichus quadrifoveolatus Letznner, 1852 & 1.06 & 15.53 & 0.31 \\
\hline Pterostichus oblongopunctatus (Fabricius, 1787) & 15.74 & 2.98 & 0.77 \\
\hline \begin{tabular}{|l|} 
Pterostichus melanarius (Illiger, 1798) \\
\end{tabular} & 0.64 & 0.42 & - \\
\hline Calathus erratus (C. Sahlberg, 1827) & - & 3.40 & 1.34 \\
\hline Calathus melanocephalus (Linnaeus, 1758) & - & 0.21 & 0.15 \\
\hline Calathus micropterus (Duftschmid, 1812) & 20 & 0.85 & 2.61 \\
\hline Agonum sexpunctatum (Linnaeus, 1758) & - & 0.21 & 0.15 \\
\hline Synuchus vivalis (Illiger, 1798) & - & 0.42 & 0.31 \\
\hline Amara plebeja $($ Gyllenhal, 1810$)$ & - & - & 0.15 \\
\hline Amara communis (Panzer, 1797) & 1.91 & - & 0.61 \\
\hline Amara lunicollis Schiødte, 1837 & - & 1.06 & 0.15 \\
\hline **Amara montivaga Sturm, 1825 & - & - & 0.15 \\
\hline Amara ovata (Fabricius, 1792) & - & 0.21 & 0.15 \\
\hline Amara tibialis (Paykull, 1798) & - & - & 0.31 \\
\hline Amara bifrons (Gyllenhal, 1810) & - & - & 0.46 \\
\hline Amara brunnea (Gyllenhal, 1810) & 0.42 & - & 0.46 \\
\hline Amara ingenиа (Duftschmid, 1812) & - & 0.21 & - \\
\hline Amara consularis (Duftschmid, 1812) & - & - & 0.31 \\
\hline Amara fulva (Müller, 1776) & - & - & 0.15 \\
\hline Anisodactylus nemorivagus (Duftschmid, 1812) & 0.21 & 0.42 & 0.31 \\
\hline Harpalus griseus (Panzer, 1796) & 0.21 & 0.42 & 0.15 \\
\hline Harpalus rufipes (DeGeer, 1774) & - & 11.70 & 6.31 \\
\hline Harpalus laevipes Zetterstedt, 1828 & 0.85 & - & - \\
\hline Harpalus rubripes (Duftschmid, 1812) & - & 0.42 & 2.61 \\
\hline Harpalus pumilus Sturm, 1818 & - & - & 0.77 \\
\hline Harpalus latus (Linnaeus, 1758) & 0.21 & - & 0.46 \\
\hline Harpalus progrediens Schauberger, 1922 & - & - & 0.61 \\
\hline Harpalus xanthopus winkleri Schauberger, 1923 & - & 0.21 & 0.61 \\
\hline Harpalus luteicornis (Duftschmid, 1812) & 0.21 & - & - \\
\hline Harpalus tardus (Panzer, 1796) & 0.21 & 0.85 & 3.54 \\
\hline Harpalus smaragdinus (Duftschmid, 1812) & - & - & 0.31 \\
\hline Harpalus distinguendus (Duftschmid, 1812) & - & - & 0.31 \\
\hline Ophonus azureus (Fabricius, 1775) & - & - & 0.15 \\
\hline \begin{tabular}{|l} 
Microlestes maurus (Sturm, 1827) \\
\end{tabular} & 0.64 & - & - \\
\hline Microlestes minutulus (Goeze, 1777) & - & - & 0.46 \\
\hline Total number of exemplars & 1324 & 375 & 487 \\
\hline Shannon Index & 0.898 & 2.557 & 2.724 \\
\hline Simpson Index & 0.661 & 0.125 & 0.136 \\
\hline Number of species & 20 & 31 & 49 \\
\hline
\end{tabular}

\section{Number of species}

Note: * indicates species found for the first time in the fauna of the Republic of Mordovia; ** indicate species found for the first time in the fauna of the Mordovia State Nature Reserve. 


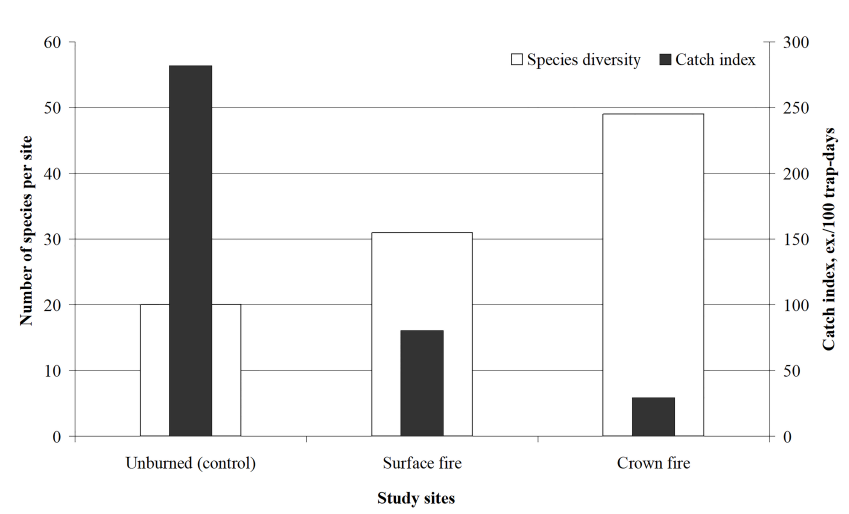

Fig. 2. The number of species and dynamic density of the carabids at different sites.

The Meshera National Park (Ryazan region, Russia) has a vegetation structure similar to the one in the Mordovia State Nature Reserve. In this Protected Area Matalin et al. (2017) indicated similar data. Authors noted that the number of the carabid species was much lower on burned sites than in the unburned areas within pine forests. At the same time, the general patterns, species diversity, and composition of the dominant carabids on the burned/unburned sites in Matalin et al. (2017) were almost identical.

The Carabus and Pterostichus species are characterised by soil-dwelling and litter-soildwelling larvae. In general, these beetles dominated in terms of their dynamic density on the UB site (to compare the Carabidae genera, see Bondarenko et al., 2017). Despite the low dynamic density, these species were dominants on the SF site. However, we noted an increase in the dynamic density of the following genera: Poecilus, Harpalus and Bembidion. In the areas damaged by crown fire, we observed an increase in the species diversity of Amara, Calathus, Harpalus genera under the conditions of the low (until minimal) dynamic density. This is primarily caused by their ability to fly and life form diversity. These capabilities allow these beetle species to actively penetrate into the exposed surfaces of the burnt sites, formed after a burn up of mosses and litter. The study of carabid communities on fire-damaged sites in the Oksky State Nature Reserve and Bashkirsky State Nature Reserve showed the absence of certain hygrophilous and typical forest species (Potapova, 1984). At the same time, the carabid species of open biotopes (Synuchus vivalis (Illiger, 1798), Poecilus lepidus (Leske, 1785), Harpalus tardus (Panzer, 1796)) have become more abundant. The appearance of some species (Notiophilus biguttatus, Bembidion lampros (Herbst, 1784)) has also been noted in fire-damaged areas in Norway (Gongalsky et al., 2006). It is noteworthy that in the Mordovia State Nature Reserve, the dynamic density of the above-mentioned species on the fire-damaged sites exceeded the one on the control site. It is confirmed by data that an increase in the tree crown density contributes to the appearance of forest species. On the contrary, a decrease in the number of trees leads to a decline in the number of these species (Niemelä et al., 1996; Saint-Germain et al., 2005).

Wildfire could be of different intensity, seasonality, rate, coverage, and unevenness of combustible materials. Therefore wildfire could have a difference influence on the forest soil-plant conditions and, consequently, on the soil fauna and herpethobiont fauna (Neary et al., 1999; Roloff et al., 2005; Gongalsky et al., 2006; Bezkorovainaya et al., 2007; Zaitsev et al., 2016; Gongalsky, 2017). Carabids are traditionally considered as quite reliable indicators of changes in the soil-plant conditions and their habitats (Sharova, 1981). Hence, a change in the species diversity and abundance of different life forms in carabids is one of the adequate responses to the above-mentioned influence. We identified two main life-form classes of carabids: myxophytophagous and zoophagous species (Fig. 3). We demonstrated the tendency to increase of the species number in both life form classes from the control site to the site damaged by crown fire (Fig. 3).
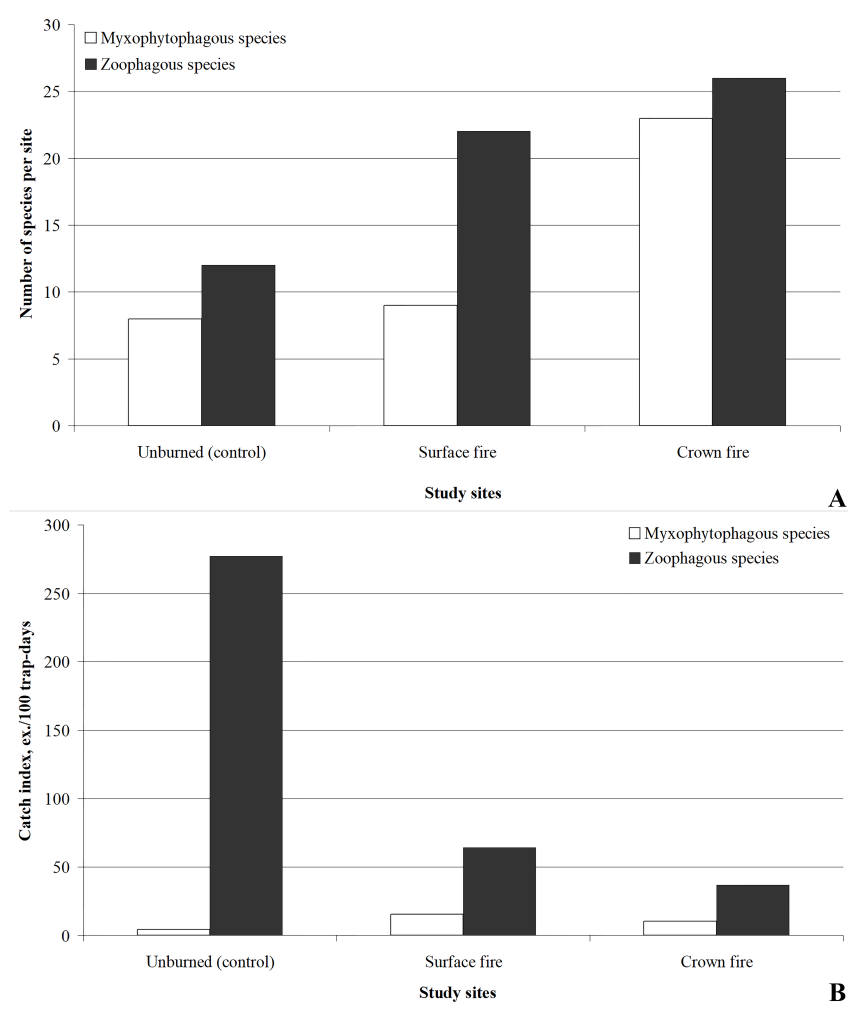

Fig. 3. The number of species (A) and dynamic density (B) of carabid life forms on different sites. 
Amongst zoophagous species, we identified the appearance of the running-digging geobionts (adults) after the wildfire impact. These carabid beetles, like Broscus cephalotes (Linnaeus, 1758) and Miscodera arctica, actively pave burrows in the soil, which has become open and loose after burning of the litter and surface plant roots. They predate at the soil surface and hide in burrows during daytime. Their larvae belong to the litter-soil hemicryptobionts. Obviously, the consequences of wildfire influence (woody vegetation reduction, thinning of forest crowns, appearance of open areas, etc.) allowed the tiger beetles (Cicindelinae) to inhabit the forest ecosystems. Their adults belong to the life form of flying epigeobionts (having well-developed wings), while their larvae belong to the soil burrowing forms. The beetles of this xerothermophilic life form are active during daylight, as a rule by sunny weather. They are predators of various invertebrates at the soil surface, while the larvae dig vertical burrows where they lie in waiting for prey.

The increase in the total number of myxophytophagous species on fire-damaged sites was obvious. At first, it concerned the adults of harpaloid geochortobionts. Their larvae are burrowing cryptobionts (Sharova, 1981). All adults of this group found on the fire-damaged sites are good flyers. Many of them more often inhabit open biotopes (e.g. meadows, forest edges, water body shores, arable lands, gardens). However, the dynamic density of cryptobionts, e.g. Amara brunnea (Gyllenhal, 1810) and Harpalus laevipes, was considerably lower on the fire-damaged sites due to the decrease in the abundance of forest carabids. Thus, in the fire-damaged areas of the Mordovia State Nature Reserve, we noted an increase in the number of carabid life forms, especially meadow forms, with considerably lower values of the total dynamic density of carabid species than on unburned (control) site. At the same time, the impact of surface fires provides the maximal diversity of the life forms.

\section{Conclusions}

According to numerous data, the carabids tend to actively colonise burned areas. And the recovery process of their communities involves decreasing abundances back to the abundance in the control areas (Zaitsev et al., 2016). In areas damaged by the 2010 wildfire in the Mordovia State Nature Reserve, the carabid species diversity is being restored at the expense of meadow forms. After the wildfire impact, the carabid species diversity has increased, while the total dynamic density of species has de- clined. It causes the increase of Shannon Index values in these areas with a significant decrease of the Simpson Index values. On the unburned (control) site, the clear dominance of some carabid species was noted, and Shannon and Simpson indices had an inverse dependence. The Jaccard similarity indices between control and burned sites did not exceed 28-34\%, whereas the similarity of species compositions of sites damaged by surface fire and crown fire was $43 \%$. The myxophytophagous and zoophagous carabids are the two main classes of the carabid life forms. The dynamic density of species clearly was increasing in both classes of the life forms from the control site to the sites damaged by crown fire.

\section{Acknowledgements}

We are grateful to Anna V. Gubina (Joint Directorate of the Mordovia State Nature Reserve and National Park «Smolny», Russia) for helping translate the text into English.

\section{References}

Aakala T., Pasanen L., Helama S., Vakkari V., Drobyshev I., Seppa H., Kuuluvainen T., Stivrins N., Wallenius T., Vasander H., Holmstrom L. 2018. Multiscale variation in drought controlled historical forest fire activity in the boreal forests of eastern Fennoscandia. Ecological Monographs 88(1): 74-91. DOI: 10.1002/ecm.1276

Arnold K.T., Murphy N.P., Gibb H. 2017. Post-fire recovery of litter detritivores is limited by distance from burn edge. Austral Ecology 42(1): 94-102. DOI: 10.1111/aec. 12404

Bayanov N.G. 2015. Climate changes of the northwest of Mordovia during the period of existence of the Mordovia Reserve according to the meteorological observations in Temnikov. Proceedings of the Mordovia State Nature Reserve 14: 212-219. [In Russian]

BC Wildfire Service. 2018. Fire Rank. Available from: https:// www2.gov.bc.ca/gov/content/safety/wildfire-status/ about-bcws/wildfire-response/fire-characteristics/rank

Bezkorovainaya I.N., Krasnoshchekova E.N., Ivanova G.A. 2007. Transformation of soil invertebrate complex after surface fires of different intensity. Biology Bulletin 34(5): 517-522. DOI: 10.1134/S1062359007050159

Bondarenko A.S., Zamotajlov A.S., Shchurov V.I. 2017. Contribution to biology and distribution studies on some ground beetles species (Coleoptera, Carabidae) registered in the Red Data Book of Krasnodarsky Krai. Nature Conservation Research 2(Suppl. 1): 70-80. DOI: $10.24189 /$ ncr.2017.005

Brown P.M. 2006. Climate effects on fire regimes and tree recruitment in Black Hills ponderosa pine forests. Ecology 87(10): 2500-2510. DOI: 10.1890/0012-9658(2006)87[2500:CEOFRA]2.0.CO;2

Buddlea C.M., Langorb D.W., Pohlb G.R., Spencec J.R. 2006. Arthropod responses to harvesting and wildfire: Implications for emulation of natural disturbance in 
forest management. Biological Conservation 128(3): 346-357. DOI: 10.1016/j.biocon.2005.10.002

Burakowski B. 1989. Agonum (Sericoda) quadripunctatum (De Geer) - a pyrophilous beetle and its immature stages Coleoptera, Carabidae. Annales Zoologici 42(6): 181-194.

Butenko K.O., Gongalsky K.B., Korobushkin D.I., Ekschmitt K., Zaitsev A.S. 2017. Forest fires alter the trophic structure of soil nematode communities. Soil Biology and Biochemistry 109: 107-117. DOI: 10.1016/j.soilbio.2017.02.006

Carcaillet C., Bergman I., Delorme S., Hornberg G., Zackrisson O. 2007. Long-term fire frequency not linked to prehistoric occupations in northern Swedish boreal forest. Ecology 88(2): 465-477. DOI: 10.1890/0012-9658(2007)88[465:LFFNLT]2.0.CO;2

Certini G. 2005. Effects of fire on properties of forest soils: a review. Oecologia 143(1): 1-10. DOI: 10.1007/ s00442-004-1788-8

Coleman T.W., Rieske L.K. 2006. Arthropod response to prescription burning at the soil-litter interface in oak-pine forests. Forest Ecology and Management 233(1): 5260. DOI: 10.1016/j.foreco.2006.06.001

Divoky V. 1989. Miscodera arctica (Paykull, 1798) - new species for Czechoslovakia (Coleoptera, Carabidae). Acta Entomologica Bohemoslovaca 86(4): 306-307.

Erikstad K.E., Byrkjedal I., Kalas J.A. 1989. Resource partitioning among seven carabid species on Hardangervidda, southern Norway. Annales Zoologici Fennici 26(2): 113-120.

Erni S., Arseneault D., Parisien M.A., Begin Y. 2017. Spatial and temporal dimensions of fire activity in the fireprone eastern Canadian taiga. Global Change Biology 23(3): 1152-1166. DOI: $10.1111 /$ gcb.13461

Feoktistov V.F. 1978. Composition and ecological structure of carabid fauna in phytocoenotic series of the Mordovia State Nature Reserve. In: Fauna and ecology of invertebrate animals. Moscow. P. 53-67. [In Russian]

Garcia-Orenes F., Arcenegui V., Chrenkova K., Mataix-Solera J., Molto J., Jara-Navarro A.B., Torres M.P. 2017. Effects of salvage logging on soil properties and vegetation recovery in a fire-affected Mediterranean forest: a two year monitoring research. Science of the Total Environment 586: 1057-1065. DOI: 10.1016/j.scitotenv.2017.02.090

Gongalsky K.B. 2011. The spatial distribution of large soil invertebrates on burned areas in xerophilous ecosystems of the Black Sea coast of the Caucasus. Arid Ecosystems 17(4): 260-266. DOI: 10.1134/S2079096111040068

Gongalsky K.B. 2014. Forest fires and soil fauna. Moscow: KMK Scientific Press Ltd. 169 p. [In Russian]

Gongalsky K.B. 2017. Perfugia as a mechanism for the recovery of soil fauna after ecosystem disturbances. Russian Journal of Ecosystem Ecology 2(4). DOI: 10.21685/2500-0578-2017-4-3

Gongalsky K.B., Persson T. 2013. Recovery of soil macrofauna after wildfires in boreal forests. Soil Biology and Biochemistry 57: 182-191. DOI: 10.1016/j.soilbio.2012.07.005

Gongalsky K.B., Wikars L.-O., Persson T. 2008. Ground beetle (Coleoptera: Carabidae) responses to a forest wildfire in northern Europe. Russian Entomological Journal 17(3): 273-282.
Gongalsky K.B., Midtgaard F., Overgaard H.J. 2006. Effects of prescribed forest burning on carabid beetles (Coleoptera: Carabidae): a case study in south-eastern Norway. Entomologica Fennica 17(3): 325-333.

Grishutkin O.G. 2012. Influence of 2010 wildfire in the mire ecosystems of the Mordovia State Nature Reserve. Proceedings of the Mordovia State Nature Reserve 10: 261-266. [In Russian]

Hengeveld R. 1980. Qualitative and quantitative aspects of the food of ground beetles (Coleoptera, Carabidae) - a Review. Netherlands Journal of Zoology 30(4): 555 563. DOI: 10.1163/002829679X00188

Holliday N.J. 1991. Species responses of carabid beetles (Coleoptera: Carabidae) during post-fire regeneration of boreal forest. Canadian Entomologist 123(6): 1369 1389. DOI: 10.4039/Ent1231369-6

Holliday N.J. 1992. The carabid fauna (Coleoptera: Carabidae) during postfire regeneration of boreal forest: properties and dynamics of species assemblages. Canadian Journal Zoology 70(3): 440-452. DOI: 10.1139/z92-067

Hornberg G., Josefsson T., DeLuca T.H., Higuera P.E., Liedgren L., Ostlund L., Bergman I. 2018. Anthropogenic use of fire led to degraded scots pine-lichen forest in northern Sweden. Anthropocene 24: 14-29. DOI: 10.1016/j.ancene.2018.10.002

Jaccard P. 1901. Étude comparative de la distribution florale dans une portion des Alpes et du Jura. Bulletin de la Societe Vaudoise des Sciences Naturelles 37: 547-549.

Khapugin A.A., Vargot E.V., Chugunov G.G. 2016. Vegetation recovery in fire-damaged forests: a case study at the southern boundary of the taiga zone. Forestry Studies 64: 39-50. DOI: 10.1515/fsmu-2016-0003

Koivula M.J. 2011. Useful model organisms, indicators, or both? Ground beetles (Coleoptera, Carabidae) reflecting environmental conditions. ZooKeys 100: 287-317. DOI: $10.3897 /$ zookeys.100.1533

Koivula M., Spence J.R. 2006. Effects of post-fire salvage logging on boreal mixed-wood ground beetle assemblages (Coleoptera, Carabidae). Forest Ecology and Management 236(1): 102-112. DOI: 10.1016/j.foreco.2006.09.004

Koltz A.M., Burkle L.A., Pressler Y., Dell J.E., Vidal M.C., Richards L.A., Murphy S.M. 2018. Global change and the importance of fire for the ecology and evolution of insects. Current Opinion in Insect Science 29: 110-116. DOI: 10.1016/j.cois.2018.07.015

Kral K.C., Limb R.F., Harmon J.P., Hovick T.J. 2017. Arthropods and fire: previous research shaping future conservation. Rangeland Ecology and Management 70(5): 589-598. DOI: 10.1016/j.rama.2017.03.006

Kryzhanovskij O.L., Belousov I.A., Kabak I.I., Kataev B.M., Makarov K.V., Shilenkov V.G. 1995. A Checklist of the Ground-Beetles of Russia and Adjacent Lands (Insecta, Coleoptera, Carabidae). Sofia - Moscow: PENSOFT Publishers. $271 \mathrm{p}$.

Kuznetsov N.I. 1960. Vegetation of the Mordovia State Nature Reserve. Proceedings of the Mordovia State Nature Reserve 1: 129-220. [In Russian]

Lemdahl G., Buckland P.I., Mortensen M.F. 2014. Lateglacial insect assemblages from the Palaeolithic site Slotseng: 
new evidence concerning climate and environment in SW Denmark. Quaternary International 341: 172-183. DOI: $10.1016 /$ j.quaint.2014.01.050

Löbl I., Löbl D. (Eds.). 2017. Catalogue of Palaearctic Coleoptera. Revised and updated revision. Vol. 1. Archostemata-Myxophaga-Adephaga. Lieden-Boston: Brill. 1443 p. DOI: 10.1163/9789004330290

Magurran A.E. 1996. Ecological diversity and its measurement. London: Chapman \& Hall. 179 p.

Makarov K.V., Kryzhanovskit O.L., Belousov I.A., Zamotajlov A.S., Kabak I.I., Kaaev B.M., Shilenkov V.G., Matalin A.V., Fedorenko D.N., Komarov E.V. 2018. Systematic list of carabid beetles (Carabidae) of Russia. Available from: http://www.zin.ru/Animalia/Coleoptera/ rus/car_rus.htm [Retrieved on 08.12.2018]. [In Russian]

Martikainen P., Kouki J., Heikkala O. 2006. The effects of green tree retention and subsequent prescribed burning on ground beetles (Coleoptera: Carabidae) in boreal pine-dominated forests. Ecography 29(5): 659-670. DOI: $10.1111 / \mathrm{j} .2006 .0906-7590.04562 . \mathrm{x}$

Matalin A., Trushitsina O.S., Makarov K.V. 2017. Influence of different types of wildfire on the community structure of ground beetles (Coleoptera, Carabidae) in pine forests of the Meshchera Lowlands. In: $18^{\text {th }}$ European Carabidologist Meeting (25-29 September 2017). Rennes, France. P. 87.

Moretti M., Duelli P., Obrist M. 2006. Biodiversity and resilience of arthropod communities after fire disturbance in temperate forests. Oecologia 149(2): 312-327. DOI: 10.1007/s00442-006-0450-z

Neary D.G., Klopatek C.C., DeBano L.F., Ffolliott P.F. 1999. Fire effects on belowground sustainability: a review and synthesis. Forest Ecology and Management 122(1-2): 51-71. DOI: 10.1016/S0378-1127(99)00032-8

Niemelä J., Haila Y., Punttila P. 1996. The importance of small-scale heterogeneity in boreal forests: variation in diversity in forest-floor invertebrates across the succession gradient. Ecography 19(3): 352-368. DOI: 10.1111/j.1600-0587.1996.tb01264.x

Niemelä J., Koivula M., Kotze D.J. 2007. The effects of forestry on carabid beetles (Coleoptera: Carabidae) in boreal forests. Journal Insect Conservation 11(1): 5-18. DOI: $10.1007 / \mathrm{s} 10841-006-9014-0$

Niklasson M., Granström A. 2000. Numbers and sizes of fires, long-term spatially explicit fire history in a Swedish boreal landscape. Ecology 81(6): 14841499. DOI: 10.1890/0012-9658(2000)081[1484:NA SOFL]2.0.CO;2

Novenko E.Y., Mazei N.G., Kupriyanov D.A., Tsyganov A.N., Payne R.J., Chernyshov V.A., Mazei Y.A., Volkova E.M. 2018. Vegetation dynamics and fire history at the southern boundary of the forest vegetation zone in European Russia during the middle and late Holocene. Holocene 28(2): 308-322. DOI: 10.1177/0959683617721331

Paquin P. 2008. Carabid beetle (Coleoptera: Carabidae) diversity in the black spruce succession of eastern Canada. Biological Conservation 141(1): 261-275. DOI: 10.1016/j.biocon.2007.10.001
Potapova N.A. 1984. Carabid fauna in the recovering firedamaged areas. In: Issues of Soil Zoology. Vol. 2. Ashkhabad. P. 60-61. [In Russian]

Roloff G.J., Mealey S.P., Clay Ch., Barry J., Yanish C., Neuenschwander L. 2005. A process for modeling short- and long-term risk in the southern Oregon Cascades. Forest Ecology and Management 11(1-2): 166190. DOI: 10.1016/j.foreco.2005.02.006

Ruchin A.B. 2016. Mesofauna of selected quarters in the Mordovia State Nature Reserve at the next year after the 2010 wildfire. Proceedings of the Mordovia State Nature Reserve 17: 183-186. [In Russian]

Ruchin A.B., Egorov L.V. 2018. Fauna of longicorn beetles (Coleoptera: Cerambycidae) of Mordovia. Russian Entomological Journal 27(2): 161-177. DOI: 10.15298/rusentj.27.2.07

Ruchin A.B., Mikhailenko A.P. 2018. Fauna of mantids and orthopterans (Insecta: Mantodea, Orthoptera) of the Mordovia State Nature Reserve, Russia. Biodiversitas 19(4): 1194-1206. DOI: 10.13057/biodiv/d190403

Ruchin A.B., Egorov L.V., Alexeev S.K., Artaev O.N. 2016. Carabid beetles of the Mordovia State Nature Reserve (annotated list of species). Moscow. 36 p. [In Russian]

Ruchin A.B., Egorov L.V., Semishin G.B. 2018. Fauna of click beetles (Coleoptera: Elateridae) in the interfluve of Rivers Moksha and Sura, Republic of Mordovia, Russia. Biodiversitas 19(4): 1352-1365. DOI: 10.13057/biodiv/d190423

Ryan K.C. 2002. Dynamic interactions between forest structure and fire behavior in boreal ecosystems. Silva Fennica 36: 13-39.

Saint-Germain M., Larrivée M., Drapeau P., Fahrig L., Buddlea C.M. 2005. Short-term response of ground beetles (Coleoptera: Carabidae) to fire and logging in a spruce-dominated boreal landscape. Forest Ecology and Management 212(1-3): 118-126. DOI: 10.1016/j.foreco.2005.03.001

Šamonil P., Moravcova A., Pokorny P., Zackova P., Kaspar J., Vasickova I., Danek P., Novak J., Hajkova P., Adam D., Leuschner H.H. 2018. The disturbance regime of an Early Holocene swamp forest in the Czech Republic, as revealed by dendroecological, pollen and macrofossil data. Palaeogeography, Palaeoclimatology, Palaeoecology 507: 81-96. DOI: 10.1016/j.palaeo.2018.07.001

Sazawa K., Yoshida H., Okusu K., Hata N., Kuramitz H. 2018. Effects of forest fire on the properties of soil and humic substances extracted from forest soil in Gunma, Japan. Environmental Science and Pollution Research 25(30): 30325-30338. DOI: 10.1007/s11356-018-3011-1

Sharova I.Kh. 1981. Life forms of carabid beetles (Coleoptera, Carabidae). Moscow: Nauka. 283 p. [In Russian]

Shugaev N.I., Khapugin A.A., Vargot E.V. 2015. Analysis of the first changes in vegetation cover of forests in the Mordovia State Nature Reserve after the 2010 wildfire. Proceedings of the Mordovia State Nature Reserve 14: 396-407. [In Russian]

Sieber A., Kuemmerle T., Prishchepov A.V., Wendland K.J., Baumann M., Radeloff V.C., Baskin L.M., Hostert P. 2013. Landsat-based mapping of post-Soviet land-use change to assess the effectiveness of the Oksky and Mordovsky protected areas in European Russia. Remote Sensing of Environment 133: 38-51. DOI: 10.1016/j.rse.2013.01.021 
Stambaugh M.C., Marschall J.M., Abadir E.R., Jones B.C., Brose P.H., Dey D.C., Guyette R.P. 2018. Wave of fire: an anthropogenic signal in historical fire regimes across central Pennsylvania, USA. Ecosphere 9(5): e02222. DOI: $10.1002 /$ ecs 2.2222

Swengel A.B. 2001. A literature review of insect responses to fire, compared to other managements of open habitat. Biodiversity and Conservation 10(7): 1141-1169. DOI: 10.1023/A:1016683807033

Tereshkin I.S., Tereshkina L.V. 2006. Vegetation of the Mordovia Reserve. Successive series of the successions. Proceedings of the Mordovia State Nature Reserve 7: 186-287. [In Russian]

Trushicina O.S., Matalin A.V., Makarov K.V. 2018. Spatial distribution and life cycle of the pyrophilous ground beetle Pterostichus quadrifoveolatus Letzner, 1852 (Coleoptera, Carabidae) in the forests of the Meshchera Lowland. In: XVIII All-Russian Meeting on soil zoology. Moscow: KMK Scientific Press Ltd. P. 201-202. [In Russian]
Turner M.G., Hargrove W.W., Gardner R.H., Romme W.H. 1994. Effects of fire on landscape heterogeneity in Yellowstone National Park, Wyoming. Journal of Vegetation Science 5(5): 731-742. DOI: $10.2307 / 3235886$

Ukhova N.L., Esyunin S.L., Belyaeva N.V. 1999. Fauna structure and abundance of soil mesofauna in primary succession community on the place of long herb-fern fir-spruce forest. In: Biodiversity of Protected Areas: estimation, protection, monitoring. Samara. P. 169 175. [In Russian]

Wikars L.O. 1995. Clear-cutting before burning prevents establishment of the fire-adapted Agonum quadripunctatum (Coleoptera: Carabidae). Annales Zoologici Fennici 32(4): 375-384.

Zaitsev A.S., Gongalsky K.B., Malmström A., Persson T., Bengtsson J. 2016. Why are forest fires generally neglected in soil fauna research? A mini-review. $A p$ plied Soil Ecology 98: 261-271. DOI: 10.1016/j.apsoil.2015.10.012

\title{
ПОСЛЕПОЖАРНАЯ КАРАБИДОФАУНА (COLЕOРТЕRА, CARAВIDAЕ) В ЛЕСАХ МОРДОВСКОГО ГОСУДАРСТВЕННОГО ЗАПОВЕДНИКА (РОССИЯ)
}

\author{
А. Б. Ручин ${ }^{1, *}$, С. К. Алексеев ${ }^{2}$, А. А. Хапугин ${ }^{1,3}$ \\ ${ }^{1}$ Объединенная дирекиия Мордовского государственного природного заповедника \\ имени П.Г. Смидовича и национального парка «Смольный», Россия \\ *e-mail: ruchin.alexander@gmail.com \\ 2Экологический клуб «Stenus», Россия \\ ${ }^{3}$ Тюменский государственный университет, Россия
}

\begin{abstract}
Пожары являются одними из основных экологических факторов, изменяющих местообитания и инициирующие сукцессии новых лесных сообществ. Пожарища являются эфемерными местообитаниями, представляющими широкий спектр экологических ниш, которые могут использовать многие виды насекомых. В 2016 г. нами была изучена карабидофауна (Carabidae, Coleoptera) в пострадавших от пожара сосновых лесах Мордовского государственного заповедника (Европейская Россия). Шестьдесят видов жужелиц были собраны в трех типах местообитаний: на несгоревшем участке (контроль), на участке, поврежденном верховым пожаром, и на участке, пострадавшем от низового пожара. По сравнению с контрольным участком карабидофауна пожарищ характеризовалась более высокой численностью особей и видовым разнообразием, в то время как на несгоревшем участке динамическая плотность была значительно выше. Это было связано с чрезвычайно высокой динамической плотностью Carabus arcensis на контрольном участке, в то время как на пожарищах этот показатель был ниже в десять раз. Видовое разнообразие имело тенденцию к увеличению в следующей последовательности: несгоревший лес - лес, поврежденный низовым пожаром - лес, поврежденный верховым пожаром. Видовые составы жужелиц были ожидаемо более схожими между участками, поврежденными верховым и низовым пожарами, в то время как была показана значительная разница между составами жужелиц на контрольном участке и участке, поврежденном верховым пожаром. Все виды жужелиц были разделены на две группы трофических групп - зоофагов и фитофагов. В составе обеих трофических групп видовое разнообразие увеличивалось в последовательности от несгоревшего участка до участка леса, пострадавшего от верхового пожара. Наконец, динамическая плотность некоторых видов жужелиц (например, Poecilus lepidus, P. versicolor, Harpalus tardus, H. rufipes, H. rubripes, Cicindela sylvatica) значительно увеличилась после воздействия пожара, в то время как значение этого показателя снизилось для большинства других видов. Наши результаты показали, что уничтожение пожаром древостоя может способствовать поддержанию численности некоторых видов жужелиц, то есть более крупный лесной пожар увеличивает видовое богатство фауны жесткокрылых. Наибольшая динамическая плотность жужелиц поддерживалась благодаря нескольким видам (например, Carabus arcensis, C. hortensis, Pterostichus oblongopunctatus).
\end{abstract}

Ключевые слова: видовой состав, динамическая плотность, насекомые, пожар, сила пожара, трофическая группа 